\title{
THE SENATE AND SUPREME COURT NOMINATIONS: SOME REFLECTIONS
}

\author{
Joel B. Grossman* and Stephen L. Wasby**
}

The Senate's rejections of the nominations of Clement Haynsworth and G. Harrold Carswell to the Supreme Court were the second and third in the present century and the ninth and tenth nominees formally rejected by the Senate in the history of the Court. ${ }^{1}$ Not since Grover Cleveland has a President had two successive nominees to the same seat on the Supreme Court-or even two nominees-rejected by the Senate. ${ }^{2}$

That there should be two bitter battles over a Supreme Court nomination is neither surprising nor, in itself, any cause for alarm. When the Court is closely divided on current issues, any single appointment may be viewed as having a decisive impact on a wide range of future decisions. Controversy over the Supreme Court nominations is but a healthy reflection of the key role which the Court plays in the political system. Opposition to a presidential nominee is a traditional and effective way of challenging and focusing attention

* Professor of Political Science and Director, Center for Law and Behavioral Science, University of Wisconsin, Madison. B.A. 1957, Queens Collcge; M.A. 1960, University of Iowa; Ph.D. 1963, University of Iowa.

** Associate Professor of Government, Southern Illinois University at Carbondale. B.A. 1959, Antioch College; M.A. 1961, University of Oregon; Ph.D. 1962, University of Oregon.

The authors gratefully acknowledge the assistance of Mr. Robert Raymond in data collection, and the comments of Professor Leon Epstein of the University of Wisconsin and Messrs. Donald Gregory and John Massaro, formerly of Southern Illinois University.

1. The total excludes several nominations which were never confirmed but not formally rejected by the Senate-for example, Fortas (1968) and Black (1859). Nominees formally rejected were Rutledge (1795), Wolcott (1811), Spence: (1843), Woodward (1846), Hoar (1870), Hornblower (1894), Peckham (1894), Parker (1930), Haynsworth (1969), and Carswell (1970). A total of twenty-eight presidential nominees to the Supreme Court have failed to obtain senate confirmation.

THE FOLLOWING HEREINAFTER CITATIONS WILL BE USED IN THIS ARTICLE:

J. Grossman, Lawyers and Judges: The ABA and the Politics of Judicial Selection (1965) [hereinafter cited as Grossman];

A. Mason, Harlan Fiske Stone: Pillar of the Law (1956) [hereinafter cited as Mason];

A. TODD, Justice ON TRIAL (1964) [hereinafter cited as Todd];

Hearings Before the Senate Comm. on the Judiciary lon the Nominations of Lewis F. Powell and William H. Rehnquist to the United States Supreme Court], 92d Cong., 1st Sess. (1971) [hereinafter citcd as Hearings on Powell \& Rehnquist].

2. Swindler, The Politics of "Advice and Consent," 56 A.B.A.J. 533, 536 (1970). 
upon the policies which that nominee is assumed to represent or protesting the policies of the appointing President. In particular, if the nominating President has announced the policy considerations governing his choices for the Court, thus making the nomination a major political issue, the battle lines are likely to be quickly drawn.

The focus of this article is not upon the politics or policies of the President, his nominees, or their opponents. Rather, the primary emphasis is upon the process of judicial recruitment. The defeats of Judges Haynsworth and Carswell, following shortly after the controversy over judicial ethics leading to the resignation of Justice Fortas, suggest that at least for the foreseeable future Supreme Court nominees will receive far more scrutiny from the Senate than has traditionally been the case. Indeed, the confrontation between President Nixon's asserted constitutional prerogative to designate members of the Court and the Senate's constitutional assignment to provide advice and consent on Supreme Court nominations ${ }^{3}$ has implications beyond the immediate issue of the Court's political balance.

\section{Advice and Consent: The Constitutional Issue}

Attempting to shore up dwindling support for Judge Carswell's nomination after Senate rejection of Judge Haynsworth, President Nixon wrote to Senator William Saxbe, stating:

[w] hat is centrally at issue in this nomination is the constitutional responsibility of the President to appoint members of the Court-and whether this responsibility can be frustrated by those who wish to substitute their own philosophy or their own subjective judgment for that of the one person entrusted by the Constitution with the power of appointment. The question arises whether I, as President of the United States, shall be accorded the same right of choice in naming Supreme Court Justices which has been freely accorded to my predecessors of both parties . . . .

... [I] the Senate attempts to substitute its judgment as to who should be appointed, the traditional constitutional balance is in jeopardy and the duty of the President under the Constitution impaired. ${ }^{4}$

3. U.S. CoNST. art. II, $\S 2$.

4. Letter from Richard M. Nixon to William Saxbe, March 3I, 1970, in 116 Cong. Rec. 10158 (1970). While the intent of the letter was to persuade uncommitted senators to resolve their doubts in favor of the claimed presidential prerogative, the letter may have had prccisely the opposite effect; indeed, it may have been the fatal blow to Judge Carswell's chances. Senators, including those of the President's own party, are loyal to the Senate as an institution and resist challenges to its power. Moreover, the letter challenging senatorial power and rcasserting presidential hegemony, at a time when senators of both parties were sensitive to assertions of presidential prerogative, may have sounded suspiciously similar to Prcsident Johnson's defense of dispatching American troops to Vietnam and his attacks on those who would deny the President the right to act in the national interest. 
The constitutional theory articulated by the President raises a controversial issue, namely whether the President is entrusted with the "right of choice" in naming justices and whether the Senate's role is as modest as the President implied. During the twentieth century the chief executive has largely enjoyed the prerogatives which President Nixon expressly claimed. ${ }^{5}$ These prerogatives did not, however, stem from the Constitution but resulted from expansion of executive power and acquiescence in the assertion of increased presidential prerogatives by both the Senate and the general public.

The constitutional prescription of the Senate's role of "advice and consent" has long been partially inoperative. ${ }^{6}$ Individual senators of the President's party may wield substantial influence in the nominations of lower federal court judges, even to the point of being able to block a nomination of which they disapprove. ${ }^{7}$ Although lower court judgeships represent prime patronage opportunities for senators of the President's party, Supreme Court nominations have long been widely accepted as a presidential prerogative. Accordingly, individual senators typically are neither consulted extensively nor accorded substantial influence in the appointment process.

Once the President has made a nomination, however, legislative participation in the process is ensured by the requirement of Senate confirmation. In confirmation proceedings, the Senate has normally limited its inquiry to whether a nominee's background included training, experience and judicial temperament deemed appropriate for the position. ${ }^{8}$ Notwithstanding this customary practice, nominations

5. Cf. J. Harris, The Advice and Consent of the Senate 314 (1953); Abraham \& Goldman, A Note on the Appointment of Justices of the Supreme Court of the United States, 46 A.B.A.J. 147, 222 (1960).

6. The most comprehensive treatment of the Senate's role in judicial appointments is J. Harris, The Advice and Consent of the Senate (1953). See also Grossman; R. Harris, DECISION (1971); TODD; Abraham \& Goldberg, supra note 5; Beiser, The Haynsworth Affair Reconsidered: The Significance of Conficting Perceptions of the Judicial Role, 23 VAND. L. Rev. 263 (1970); Black, A Note on Senatorial Consideration of Supreme Court Nominees, 79 YALE L.J. 657 (1970); Thorpe, The Appearance of Supreme Court Nominees Before the Senate Judiciary Committee, 18 J. Pub. L. 371 (1969).

7. McKay, Selection of United States Supreme Court Justices, 9 KaN. L. Rev. 109, 129 (1960). See Chase, Federal Judges: The Appointing Process, 51 Mins. L. Rev. 185, 188-91 (1966).

8. Neither the Constitution nor federal statutes prescribe any qualifications for a Supreme Court Justice. It is legally possible, though scarcely conceivable, that a non-citizen, a minor or a non-lawyer could be appointed to the Court. The pattern of recent appointments suggests that a nominee will be a citizen, middle-aged, a practicing lawyer or politician, hold a law 
have been challenged by senators adhering to political viewpoints different than those of the nominee; ${ }^{9}$ however, a political challenge to a nominee has succeeded only on one prior occasion in the twentieth century. ${ }^{10}$ Senators expect and normally grant to the President the right to appoint to the Court men who share the President's own political philosophy.

While President Nixon was factually correct in asserting that rejection of Judge Carswell, especially in light of the Senate's rejection of Judge Haynsworth's nomination, would circumscribe the freedom "freely accorded to my predecessors of both parties," "he was clearly mistaken in asserting that the sole constitutional responsibility to appoint justices rests with the President. Indeed, the contrary position was aptly stated by Senator Griffin, who had earlier engineered Republican strategy culminating in Justice Fortas' resignation:

There are some who suggest that the Senate's role is limited merely to ascertaining whether a nominee is qualified in the sense that he possesses some minimum measure of academic background or experience. It should be emphasized at the outset that any such view of the Senate's function with respect to nominations for the separate judicial branch of the government is wrong and simply does not square with the precedents or with the intention of those who conferred the "advice and consent" power upon the Senate."

Available historical evidence lends support to the view that the Senate was intended to undertake an independent evaluation of a

degree from an accredited, and more often than not, prestigious law school, be almost always of the same political persuasion as the President, and, until at least the present, be a male.

9. See W. Burris, John J. Parker and Supreme Court Policy: A Case Study in Judicial Control, 1965 (unpublished thesis in University of North Carolina Library). However, nominations to the Supreme Court in the 18th and 19th centuries were expected to be subject to politically motivated attacks. The rejection of Rutledge in 1795 was primarily a result of the nominee's views on the Jay Treaty. 1 C. WARREN, THE SUPREME CourT IN THE UNITED STATES HISTORY 124-38 (1922). Other examples of nominations rejected, at least partially, on partisan grounds would include Wolcott's in 1811, id. at 410-13, Crittenden's in 1829, 2 id. at 160.64, and the failure to confirm Black for his views on slavery and secession in, 3 id. at 86 . A perusal of Professor Warren's book will reveal many additional instances.

10. Swindler, supra note 2, at 536.

11. Letter from Riehard M. Nixon to William Saxbe, March 31, 1970, in 116 Cong. REc. 10158 (1970). See text accompanying note 4 supra.

12. 116 CoNG. Rec. 10183-84 (1970). Griffin was writing at the time of the Fortas controversy, presumably in defense of his mobilization of the anti-Fortas bloc. Senator Tydings, in connection with the Carswell debate, introduced Griffin's views. Ironically, the position had been adopted a number of years earlier by William Rehnquist, as his opponents were fond of pointing out. See Rehnquist, The Making of a Supreme Court Justice, HARv. L. REC., Oct. 8, 1959 , at 7 . 
nominee's qualifications. For example, Hamilton anticipated that the Senate would fully consider the qualifications of nominees, ${ }^{13}$ although he did argue that a nominee should not be rejected merely because the Senate preferred a different candidate..$^{14}$

In support of President Nixon's position, the argument may be made that, as with Cabinet appointments, a presumption of fitness should be enjoyed by a presidential nominee, and that, accordingly, the Senate should sustain a heavy burden of proof before rejecting a candidate. However, this argument is fundamentally unsound because of obvious differences between the functions, as well as tenure, of Cabinet officers and Supreme Court Justices. ${ }^{15}$ In addition to the limited duration of office holding inherent in a Cabinet post, executive positions are distinguishable from Supreme Court posts on the grounds that incompetence or malfeasance displayed in the former offices will result in negative political consequences for the President. Supreme Court Justices, on the other hand, are not "the President's men"; therefore, presidential responsibility for the conduct of justices is severely attentuated. Moreover, in the highly politicized circumstances surrounding the nomination of Judge Carswell, it was difficult for the President to argue convincingly that the Senate, in considering a Court nomination, should not concern itself with factors which originally prompted the President's action itself. Having made a nomination for express policy and partisan reasons, the President could not reasonably expect the Senate to react in a non-partisan fashion.

Even if the President's constitutional arguments were more defensible, it would have been difficult to convince the Senate to adopt his view in the Carswell case. Constitutionally prescribed roles for judi-

13. If it be said [the Senate] might sometimes gratify [the President] by an acquiescense in a favorite choice, when public motives might dictate a different conduct, I answer that the instances in which the President could be personally interested in the result, would be too few to admit of his being materially affected by the compliances of the Senate. The POWER which can originate the disposition of honors and emoluments, is more likely to attract than to be attracted by the POWER which can merely obstruct their course. If by influencing the President be meant restraining him, this is precisely what must have been intended. And it has been shown that the restraint would be salutory, at the same time that it would not be such as to destroy a single advantage to be looked for from the uncontrolled agency of that Magistrate. The right of nomination would produce all the good of that appointment, and would in great measure avoid its evils. The Federalist No. 77, at 485-86 (B. Wright ed. 1961) (A. Hamilton).

See id. No. 76, at 483 (A. Hamilton); Grossman 26-27; J. HaRRIS, supra note 5, at 27-28.

14. The Federalist No, 66 (B. Wright ed. 1961) (A. Hamilton).

15. See Black, supra note 6 , at 659-60. 
cial selection, it must be remembered, were devised before the advent of the party system, and the process as it has evolved bears only slight resemblance to that envisioned by the framers. Thus, the primary question was not only whether the President was asserting a more "correct" view of the constitutional issue, but whether it was politically tenable for the Senate to accept it. In most Supreme Court and lower federal court nominations, the Senate does not experience a conflict of pressures between claimed presidential prerogatives and the legislative role of conducting an independent evaluation of a nominee's competence. Ordinarily, the nominee is qualified; consequently, in such circumstances no compelling reason exists to dissent from the tradition of deference to presidential choice. Where conflicting pressures do exist, however, deference becomes less tenable, and the Senate is forced to give full consideration to the qualifications of a Supreme Court nominee. ${ }^{16}$

16. By what criteria should a senator decide to vote for or against a Supreme Court nominee? An individual senator's policy is undoubtedly the result of a number of factors, including party loyalty, loyalty to the President, and the impact of a vote on the senator's constituents. Inertia and tradition always favor a vote for confirmation-or at least no recorded opposition-although these factors may be given different weight when applied to Cabinet and Supreme Court nominations. In the debate over confirmation of Lewis F. Powell and William H. Rehnquist, two senators spoke directly to this question. Senator Javits (R., N.Y.) articulated the following six-point test for confirmation: a Supreme Court nominee should display (1) a high commitment to freedom, dignity and justice for all citizens; (2) a high level of professional competence as a lawyer and personal integrity; (3) high intellectual ability and a recognition of broad social, economic and governmental concerns; (4) a sense of objectivity and an understanding of the Supreme Court's role; (5) an understanding of the constitutional limits of the executive and legislative branches with respect to individual liberties, especially where the poor and unpopular groups are concerned; (6) an understanding of the constitutional limits on judicial power. 117 Cong. Rec. 16602 (daily ed. Oct. 20, 1971). Since he voted to oppose confirmation, one may assume that Senator Javits believed Rehnquist deficient in one or more of these categories. More important for prcsent purposes, these standards suggest the need for an independent consideration of a nominee's qualifications by the Senate, rather than a passive acquiescence in a presidential choice.

On the other hand, Senator Proxmire (D., Wis.) announced that he would-and did-vote for Mr. Rehnquist's confirmation. Recalling that he had opposed Judge Haynsworth because of the conflict of interest allegations, and Judge Carswell because of lack of ability, Senator Proxmire stated that the Senate should confirm a nominee of obvious intellectual ability, such as Rehnquist, without consideration of any substantive views which he might hold, unless it could be shown that the nominee did not understand or would not support the Bill of Rights and other constitutional protections. 117 Cong. REC. 20827 (daily ed. Dec. 8, 1971). Thus, while Senator Proxmire found insufficient negative characteristics about Rehnquist to vote in opposition, Senator Javits articulated an affirmative test which placed the burden of proof on a nominee or his supporters. 


\section{Advice and Consent: The Process of Senate Confirmation}

Supreme Court nominations ${ }^{17}$ are normally referred to the Senate Judiciary Committee for investigation and public hearings. ${ }^{18}$ Upon completion of the hearings, the nomination, accompanied by the Committee's report, is sent to the Senate floor.

To determine the rapidity of Senate action on nominations, two factors must be examined: first, the interval between the nomination and its being reported by the Committee to the Senate; and, second, the interval between the date of the Committee report and the Senate's vote on confirmation. One crude index of the level of controversy surrounding a nomination is the length of the Senate Committee hearings. The Committee hearings tend to be pro forma in character where nominations are non-controversial. If there is significant opposition, however, the hearings may be used either to mobilize support for a nominee by eliciting testimony from favorable witnesses or to mobilize opposition by presentation of adverse testimony. However, considering both time lapse factors, it should be noted that delay may also be used to advance or protect senatorial political fortunes and may, therefore, indicate little about the actual level of substantive controversy; it may symbolize senatorial unrest over a key political issue with which the nominee is prominently associated; it may represent an indirect attack on the Supreme Court itself as an expression of senatorial unhappiness with particular decisions; and, finally, delay may represent an attack on the President rather than the nominee. One-day hearings have definitely been the rule in the past. In only fourteen of the nominations has more than one day of hearings been conducted, and in only four instances have more than four days been involved. ${ }^{19}$ However, the "one-day" rule has

17. Although the Senate has rejected only three nominations since the HornblowerWheeler-Peckham rejections of 1894, in the twentieth century there have been fifty-one Supreme Court nominations, including nominations to the position of Chief Justice. This total, through the end of 1971 , includes the nomination of Justice White, who originally reached the Court before 1900 and became Chief Justice in 1910; the two nominations of Harlan Stone, first appointed in 1925 and named Chief Justice in 1941; and Abe Fortas, nominated in 1965, and then unsuccessfully nominated to be Chief Justice in 1968. Charles Evans Hughes was nominated in 1910 and then again in 1930, after he had resigned from his initial service. The nomination of Abe Fortas was withdrawn after the Senate failed to vote cloture on the debate, and the nomination of Judge Homer Thornberry was withdrawn at the same time.

18. For a discussion of the Senate Judiciary Committee hearings, see Grossman 156-95.

19. Hearings on Thurgood Marshall's nomination lasted five days, Clement Haynsworth, eight days, and Abe Fortas, eleven days. The longest were those on Louis D. Brandeis, where the Committee held nineteen days of hearings in addition to taking an additional six days for 
recently weakened, and, since 1950 , a majority of hearings have extended for at least two days. ${ }^{20}$

A second partial index of the level of controversy surrounding a nomination is the time elapsing between the nomination by the President and a final vote by the Senate. In only two cases in this century have more than one hundred days elapsed beteen the nomination and the Senate Judiciary Committee's report. ${ }^{21}$ In no other cases did more than seventy days elapse between the nomination and the Committee's report. ${ }^{22}$ However, arrangement of the nominations in chronological order shows a definite increase in the period of time as the years have passed. The interval between report by the Committee and confirmation or rejection has normally been quite brief. ${ }^{23}$ Rarely has the Senate devoted more than two days for debate of Supreme Court nominations, ${ }^{24}$ and in only a few cases has any period of time elapsed

Committee consideration. Two-day hearings were devoted to the nominations of John Marshall Harlan, William Brennan, Potter Stewart and William Rehnquist. The hearings for Robert Jackson, Tom Clark and Earl Warren each consumed three days, and those for Felix Frankfurter and Harlan Stone (his first nomination) took four days each. An attempt to reopen hearings on William Rehnquist for an additional day failed by a vote of ten to five.

20. Senate Judiciary Committee hearings extended at least two days for eight of the fifteen nominees during the period in question.

21. The time elapsing between the nomination of and the Committee report on Louis Brandeis involved one hundred and twenty-two days, that of Potter Stewart one hundred and ten days. While the Committee's consideration of Brandeis has come to be recognized as a classic example of controversy and delay, the length of time in the Stewart case (measuring only the time after Eisenhower submitted his name to the Senate) resulted from the Senate's increasing irritation with the practice of recess appointments-Stewart was the third Eisenhower recess appointee. The comparable figure for Warren, the first recess appointee, was forty-nine days, and for Brennan, the second such appointee, sixty-three days.

22. The nominations of Marshall and Haynsworth took sixty-nine days to reach the report stage; other significant delays in descending order were Harlan (59), Fortas (55), Warren (49), Carswell (39), Parker (32), Butler and Goldberg (25), Rutledge (21), Burger (19) and , lackson (18). The contrast between the sixty-nine days for Haynsworth and thirty-nine days for Carswell may be explained by the Committee's desire to fill a position on the Court which had remained vacant distressingly long and a feeling of confidenee that Carswell would not encounter the same difficulties as Haynsworth. For Powell and Rehnquist, the figures are thirty-four days from the nomination to Committee vote, and forty-one days from nomination to the filing of minority views. Attempts to treat the nominations separately, with opposition focused on Rehnquist, were unsuccessful despite an alleged "trade-of"' within the Committee whereby there would be no opposition to Powell in exchange for an opportunity to defeat Rehnquist.

23. However, fifteen days elapsed before the vote on John Parker, on five of which the Senate debated the nomination.

24. The Senate took seven days, however, on Haynsworth's nomination, and five days with each of the nominations of Rehnquist, Stone and Fortas, the latter when Justice Fortas was nominated for the post of Chief Justice. Three days were devoted to Hughes' initial nomination. 
between report and the vote on confirmation. ${ }^{25}$

In addition to the time lapse between submission of the nomination by the President and Senate action, and the length of consideration of the nomination in the Senate Judiciary Committee hearings, the pattern of Senate voting in Committee and on the floor provides a third index of the controversy generated by a nomination. In only three of the fifty-one nominations (six percent) have as few as four votes separated the two sides in Committee ${ }^{26}$ Committee votes were unanimously favorable in seventy-five percent of the nominations; however, in the last two decades there has been an increasing number of split roll-call votes, with an increasing number of members in the minority. ${ }^{27}$ Nonetheless, the only Committee vote adverse to the nominee was the ten to six vote against Judge Parker in $1930 .{ }^{28}$

Voting on confirmation by the Senate follows much the same pattern-approval by either a unanimous or a decisive majority vote. Most nominees to the high court have been confirmed by voice vote. ${ }^{29}$ However, the votes on three rejections were close. In the case of Judge Parker (thirty-nine for, forty-one against), a shift of one vote could have led to confirmation. ${ }^{30}$ Judge Haynsworth's defeat was by a decisive fifty-five to forty-five margin, while Judge Carswell's nomination was rejected fifty-one to forty-five. A motion to recommit the latter's nomination to the Judiciary Committee was defeated fifty-two to forty-four immediately prior to the final vote.

There are record votes on only twenty (thirty-nine percent) of the nominations in the twentieth century, although presently there is an increasing likelihood that a roll call vote will occur and that there will

25. Seven days elapsed between the report and vote on the nominations of Jackson and Rutledge; in the case of Marshall, nine days elapsed. There are no other delays of note, and it is hard to call even these periods "delays" because of their brevity. From the Committee's vote on the nominations until the confirmation vote, thirteen days elapsed for Powell and seventeen for Rehnquist.

26: Those were the nominations of Parker, Brandeis, and Haynsworth. See notes 27-28 infra.

27. There were only five nominations with at least five negative votes-Parker, Brandeis, Haynsworth, Marshall and Fortas; four more with four negative votes-Black, Harlan, Carswell and Rehnquist; two with three negative votes-Warren and Stewart; and four others with one or two negative votcs. Thus, in only twenty-five percent of the nominations were there any opposing votes in the Judiciary Committee.

28. The only other close votes were those involving Brandeis (10-8 for), and Haynsworth (10-7 for).

29. A nominee has never been rejected by voice vote. See Swindler, supra note 2, at 536 .

30. Because Hoover's Vice-President, Charles Curtis, was presiding over the Senate, he presumably would have broken the tie in favor of the nominee. 
be some opposition to a nomination in light of increased legislative scrutiny. Despite this trend, there have been only nine instances (eighteen percent) in which there were as many as ten negative votes, and seven of these have occurred since $1949 .{ }^{31}$ That unanimous and nearly unanimous votes are not completely a thing of the past, however, is demonstrated by Justice Blackmun's unanimous confirmation and Justice Powell's confirmation by a vote of eighty-nine to one.

From a chronological examination of the votes cast, it is clear that the Senate's voting shows less of a pattern or trend toward controversy than has been the case in consideration of nominations by the Committee on the Judiciary, where the most substantial splits in voting have occurred in recent nominations. There has been no consistent growth in the extent of voting opposition to Supreme Court nominees. Indeed, the nominees, if confirmed, have received the support of a substantial majority of the Senate, even if delay and controversy were associated with the nomination..$^{32}$

\section{Advice and Consent: Factors Considered by the Senate in CONFIRMATION ProceEdings}

In the remainder of this article, we will examine the reasons why a nomination might meet with opposition in the Senate and perhaps be rejected. The rejections of Judges Parker, Carswell and Haynsworth will be emphasized, but the nominations of Brandeis, Stone, Harlan, Black, Rehnquist, Powell, and two Eisenhower recess appointees-Warren and Brennan-will also be considered. Assuming both that the "burden of proof" against confirmation must be borne by the opposition and that the institutional machinery will otherwise

31. An additional six nominees received what might be called "token" negative votes. Butler and Clark each had eight votes cast against them; the nominations of McReynolds and Stone (1926) each received six negative votes; Douglas received four negative votes; Burger received three votes in opposition, and Powell only one. Of the nominees confirmed by a divided vote, in three instances the negative vote approached one-half of the positive vote. Pitney was confirmed in 1912 by a 50-26 vote, Brandeis' nomination was confirmed by a 47-22 margin, and Hughes was confirmed by a 52-26 tally. There have been at least ten senators voting against confirmation in six otber instances-Black (63-16), Minton (48-16), Harlan (71-11), Stewart (70-17), Marshall (69-11) and Rebnquist (68-26). After a motion to close off debate on the Rehnquist nomination failed, receiving only a $40-52$ positive vote, a motion to delay the confirmation vote for five weeks failed, 22-70.

What is perhaps unusual about the size of the negative vote in the cases of Black and Minton is that both were senators, and it is the "conventional wisdom" that the Senate readily accepts "its own" when nominated by the President to another federal office.

32. See generally Abraham \& Goldberg, supra note 5 . 
operate in favor of confirmation, there appear to be instances in which controversy is more likely, and, as a corollary, acceptance of a nomination less likely.

Senate action appears to depend upon three factors. The first, obviously, is the suitability of the nominee himself. Although this factor necessarily involves a subjective judgment, several "informal" indicators are typically considered in confirmation proceedings. The nominee's performance as a lower court judge may come under extensive scrutiny, or, if he is not a nominee from the bench, his record in any legislative or administrative position formerly held will be considered as a means of assessing his judicial philosophy-his general predilection toward activism or restraint and, more specifically, the manner in which he would likely act when confronted with particular cases. In addition, senators frequently examine the nominee's past political involvement in determining suitability. ${ }^{33}$ Moreover, judicial ethics has become a highly important consideration as charges of conflict of interest multiply in appointments in all branches of government. In a complex society with economic power interlocked among numerous disparate organizations, it is increasingly likely that, by being at least indirectly involved with such organizations, a prospective public official's ability to maintain independence of judgment will be questioned. Particularly in light of the resignation of Justice Fortas, it is unlikely that any subsequent nominee will be able to avoid an extended examination of the ethical standards displayed in his professional activities. The forthrightness with which Lewis Powell dealt with the matter of his stock and property holdings, as well as his submission of a financial statement to the Senate Judiciary Committee, further supports this assertion..$^{34}$

The strategy of the President, the second relevant factor, will also influence the final outcome. The extent of presidential commitment to effecting confirmation may determine the tactics which the White House will adopt in attempting to sway potentially recalcitrant senators. Moreover, the degree of public support which the President is

33. See, e.g., Hearings on Powell \& Rehnquist $42-43$ (Rehnquist), 233-34 (Powell); Hearings Before the Senate Comm. on the Judiciary Ion the Nomination of John M. Harlan to the Supreme Court], 84th Cong., Ist Sess. 125-27, 143 (1955); Senators Bayh, Hart, Kennedy \& Tydings, Memorandum on the Qualifications of $G$. Harrold Carswell for the Supreme Court of the United States, reprinted in 116 CoNG. REC. 7360,7364 (1970).

34. Judge Carswell also took a similar course of action. Hearings Before the Senate Comm. on the Judiciary [on the Nomination of $G$. Harrold Carswell to the Supreme Court], $91 \mathrm{st}$ Cong., 2d Sess. 13-15 (1970). 
willing to give the nominee after the initial nomination is made is a critical element of White House strategy, especially in circumstances of substantial opposition to the nominee. In addition to actions of the President, a further component of strategic considerations is the public conduct of and tactics utilized by the nominee. The course of the nominee's behavior during the confirmation process may be guided, at least in part, by White House strategists.

The final factor relevant to Senate disposition of the nomination is the group support or opposition which the nominee receives. Obviously, one critical group is the bench and bar, especially when the nominee is a member of the bench at the time of his nomination. Other vital groups include organized economic blocs, such as labor organizations, and public interest groups which adopt an active role in attempting to influence legislative decision-making.

\section{Suitability of the Nominee}

Prior Judicial Service. If the nominee has served as a lower court judge, his suitability depends in large part on the decisions he promulgated in that capacity. All three nominees rejected in this century were lower court judges, a factor tending to indicate the vulnerability which such service may bring and which could perhaps inhibit the President's selection of one whose judicial record is at least partly known. Judges Parker and Haynsworth were, at the time of their nominations, members of the Court of Appeals for the Fourth Circuit, and accordingly, the proper role of a federal appellate judge became an issue with respect to both nominations. ${ }^{35}$ In each case, allegations were made that the nominees were too conservative. Judge Parker's defenders argued that his controversial rulings indicated only that the judge was implementing the law as established by the Supreme Court. ${ }^{36}$ Defenders of Judge Haynsworth argued that the nominee had not attempted to obstruct or evade compliance with Brown v. Board of Education, ${ }^{37}$ and that, at the time they were made, his key decisions in school desegregation cases, though later

35. For a discussion of the comparison between the nominations and rejections of Haynsworth and Parker, see Grossman \& Wasby, Haynsworth and Parker: History Does Live Again, 23 S.C.L. REv. 345 (1971).

36. H. Hoover, Memoirs of Herbert Hoover: The Cabinet and the Presidency $1920-1933$, at $268-69$ (1952).

37. 347 U.S. 483 (1954). 
reversed, were an accurate interpretation of the Brown decision..$^{38}$

Supreme Court precedents are only part, albeit a significant part: of the factors considered by the lower court judge in his decisionmaking. They are not the whole directing force behind his work, despite their binding nature. While Supreme Court opinions create pressure in one direction, more specific pressure may derive from the emotions of the area to be affected by a decision. The federal judge, as a resident in a district or circuit and a product in part of the local political machinery (even if he is not an active member in the party, his selection involved the party), is responsive to the social, economic and political values of the area. A study of Southern federal judges after Brown shows that while "[j]udges will do what they are told by the United States Supreme Court . . . none of them . . . are particularly anxious to attack strongly entrenched local institutions, [and that] the ambiguity of the Supreme Court's instructions has been resolved to conform to the dominant political forces of the South."39 While some pressures are centrifugal and lead the lower court judge away from the Supreme Court's rulings, it is not the case that, other things being equal, lower court judges will not follow the high court's rulings. Rather, many judges have in fact closely followed Supreme Court precedent. ${ }^{40}$ However, even if a lower court judge scrupulously adheres to precedents, notwithstanding local pressures favoring a different approach, compliance with Supreme Court directives may have high costs. For example, UMW v. Red Jacket Consolidated Coal \& Coke Co. ${ }^{41}$ was decided by Judge Parker on the authority of the Supreme Court's decision in Hitchman Coal \& Coke Co. v. Mitchell ${ }^{42}$ unholding "yellow-dog" contracts. In arguing against Judge Parker's confirmation, opponents claimed that the Red Jacket injunction was overly broad, that he had gone beyond what precedent required of him, and that he had ignored American Steel Foundries v. Tri-City Central Trades Council, ${ }^{43}$ which followed and limited Hitchman Coal. However, consideration of decisions by Parker

38. 115 CONG. REC. 34568 (remarks of Senator Baker), 35130 (remarks of Senator McCleilan), 35132 (remarks of Senator Cook) (1969).

39. See J. Peltason, Fifty-Elght Lonely Men 246 (1961).

40. Parker, for example, was consistent with the Supreme Court in 64 of 72 cases. Of the eight cases where he was not, seven had no controlling Supreme Court precedent, leaving only one of seventy-two in which he was in conflict with the high court. W. Burris, supra note 9.

41. Rowe v. Peyton, 18 F.2d 839 (4th Cir. 1927).

42. 245 U.S. 229 (1918).

43. 257 U.S. 184 (1922). 
dealing with a wide range of subjects substantiates the argument that Parker was an obedient follower of a conservative Supreme Court rather than a conservative masquerading as a judge. $.^{44} \mathrm{Sim}-$ ilarly, in the debates concerning the nomination of Judge Haynsworth, controversy focused in part upon his decision with respect to the power of company officials to close plants in the face of impending unionization. Supporters of Judge Haynsworth's nomination argucd that the decision in favor of the company followed existing Supreme Court doctrine at the time, although the Court changed the rule in reversing the judge when the case was appealed. Pressing the attack that Haynsworth was an anti-union judge, opponents pointed out that, when the Supreme Court reversed Haynsworth in labormanagement cases, it did so unanimously in all but one instance..$^{45}$

The problem of a fast-moving Supreme Court most clearly affected Haynsworth in the area of race relations. The Supreme Court, finally frustrated by the slow response to its ambiguous "with all deliberate speed" order of Brown v. Board of Education, ${ }^{46}$ began to move quickly in the late 1960's and found some of the rulings from the Fourth Circuit, as well as from other circuits, to be improper. ${ }^{47}$ Whether this made Haynsworth a segregationist, however, is quite another matter. ${ }^{48} \mathrm{~A}$ comparison of his position with that of his judicial brethren at the time he made his particular decisions show that Haynsworth was not notably out of line and clearly was not lagging behind what the Supreme Court appeared to be saying.

An evaluation of Judge Haynsworth's performance depends upon whether one expects a lower court judge to anticipate decisions of the Supreme Court and to adjust his philosophy accordingly. Signifi-

44. W. Burris, supra note 9. In support of the position that Parker was anti-union and not simply an obedient lower court judge, it can be argued that Parker ignored the Clayton Act, 15 U.S.C. $\$ 12-27$ (1970), which was passed after Hitchman Coal and limited the holding of that case. However, it should be remembered that the Supreme Court had severely limited the labor protection provided in that statute. See Duplex Printing Press Co. v. Dcering, 254 U.S. 443 (1921).

45. 115 Cong. ReC. 34428 (1969) (remarks of Senator Metcalf).

46. 349 U.S. 294, 301 (1955).

47. See Bradley v. School Bd., 382 U.S. 103, rev'g per curiam, Gilliam v. School Bd., 345 F.2d 325 (4th Cir. 1965) (Haynsworth, J.) and Bradley v. School Bd., 345 F.2d 310 (4th Cir. 1965) (Haynsworth, J.).

48. In the words of Senator Clifford Case, Haynsworth had shown "persistent reluctance to accept, and considerable legal ingenuity to avoid" the mandate of Brown and other similar cases. 115 CONG. REC. 35130 (1969). For a more sympathetic view of Haynsworth's handling of school desegregation cases, see the statement by Professor G.W. Foster to the Senate Judiciary Committee. Id. at 34453. 
cantly, Haynsworth was not notably reluctant to anticipate the Court in other areas of the law. His innovative decision on the right of prisoners to have convictions reviewed on habeas corpus was upheld by the Supreme Court in a decision praising Haynsworth. ${ }^{49}$ His supporters also pointed to his order desegregating the North Carolina Dental Society ${ }^{50}$ as an instance of judicial statesmanship. It could be concluded that Haynsworth's reluctance to anticipate school integration decisions of the Supreme Court reflected personal policy preferences rather than a desire to follow precedent. However, it must be noted that it took the Supreme Court fourteen years to decide that the Brown decision required affirmative steps toward integration ${ }^{51}$ rather than a mere dismantling of the legal barriers to integration, and fifteen years elapsed before school districts were required to proceed in this direction with more than "deliberate speed." 52

Judge Carswell had not been on the Court of Appeals for a suffcient period of time to permit a realistic evaluation of his performance as an appellate judge. His supporters, however, relied upon his temporary service with the Court of Appeals prior to his appointment as a full member of that body to demonstrate his experience as an appellate judge ${ }^{53}$ Opponents pointed to the rate at which the Fifth Circuit reversed his dccisions, while supporters argued that there were occasions when the Court of Appeals was, in turn, reversed by the Supreme Court, or that Supreme Court decisions handed down after his rulings led the Court of Appeals to reverse him..$^{54}$ However, it should be noted that the rate at which Carswell was reversed had increased over the period of his judgeship. ${ }^{55}$

\footnotetext{
49. Rowe v. Peyton, 383 F.2d 709 (4th Cir. 1967), aff d, 391 U.S. 54 (1968).

50. Hawkins v. North Carolina Dental Soc'y, 355 F.2d 718 (4th Cir. 1966).

51. Green v. County School Bd., 391 U.S. 430 (1968).

52. Alexander v. County Bd. of Educ., 396 U.S. 19 (1969).

53. 116 CONG. REC. 7673 (1970).

54. See Hearings [on the Nomination of G. Harrold Carswell], supra note 34, at 311-15.

55. The most damaging figures on Carswell's reversal record came from the Ripon Society. It reported that Carsweil was reversed more frequently than a sample of district judges either in all circuits or in the Fifth Circuit alone. Carswell was also cited less frequently than a sample of other judges and used far fewer case citations and secondary sources than other judges. 116 CONG. REC. 7493-94 (1970). Another study shows that only six of the sixty-seven district judges in the Fifth Circuit were reversed more frequently than Carswell. Id. at 10159 (remarks of Senator Bayh). A similar report on California Judge Mildred Lillie's reversals was apparently instrumental in the widespread lack of enthusiasm for her expected nomination to the Supreme Court. N.Y. Times, Oct. 19, 1971, at 23, col. 1.

A possible explanation for Carswell's reversal record is that he was willing to lend greater weight to the social values and political attitudes widely held in his region than the appellate
} 
Political Involvement. In his confirmation proceeding, Brandeis was alleged to be lacking "proper judicial temperament"-a phrase which has come to be conveniently used to encompass a wide variety of derelictions to which its users want to refer. Although on the surface, such a statement would seem to refer to ability as a judge, it usually masks criticism of the ideology he is likely to pursue while on the bench. Despite his wealth, Brandeis had been the friend of or, more accurately, the advocate for, the average citizen. His attacks on the utilities and his defense of minimum wage and maximum hour statutes incurred the wrath of many leaders of the bar..$^{56}$

While no specific charges of wrong-doing were proven, the quantity and frequency of the charges caused a long delay in the processing of the nomination and created the impression that wrong-doing was involved. ${ }^{57}$ President Wilson's firm support of Brandeis, particularly when Brandeis was under attack, likely played a major part in deflating the opposition to the nomination..$^{58}$

The controversy over Hugo Black's nomination in 1937 involved racial issues and, of more significance, the propriety of nominating a senator. While it is often assumed that the issue of Black's having been a member of the Ku Klux Klan interfered with confirmation, the issue in fact arose mainly after confirmation. ${ }^{59}$ Another controversy surrounding the nomination stemmed from the claim that because Black, as a senator, had voted for a new retirement system for

court decisions would warrant. The very fact that he was nominated to the Supreme Court suggests the possible gains from persistent adherence to a regional ideology.

56. William Howard Taft, ex-President and future Chief Justice, and other prestigious lawyers wrote letters attacking Brandeis. One observer commented that "[n]o such rallying of the leaders of the American bar has been seen in the capital before, on any issue." Tond 160. See also Grossman 181-95.

57. See Todd 96-127.

58. See A. Mason, Brandeis: A Free Man's Life 465-508 (1946); Todd 37-39, 133-39.

59. See R. Scigliano, The Supreme Court and the Presidency 106 (1971), where the author argues that Black misled the Senate into believing that stories about his KKK membership were false.

The issue of Black's KKK membership was injected into one debate over Carswell's nomination, when Senator Holland (D., Fla.) introduced a Florida newspaper editorial claiming that if Black could rise above KKK membership, Carswell could rise above his racist statement. 116 Cong. Rec. 10260 (1970). On the other side, the Dean of the Yale Law School, Louis Pollak, pointed out that Senator Black, as a lawyer, had vigorously represented black citizens in Alabama. Id. 2860 (1970). Professor William Van Alstyne emphasized that while Black's principles about human rights were quite clear from his service as a senator, the same was not true of Carswell's activities. Van Alstyne expressed considerable concern over the fact that even after the 1948 speech, Carswell had not engaged in any "reassuring conduct," but instead, only a continuing pattern of involvement in segregationist activities. Id. at 2858. 
Supreme Court Justices, which included retirement at full pay, he was ineligible to serve on the Court since he would benefit from "emoluments" he had helped establish. ${ }^{60}$ In addition, some senators were upset over the practice by which the Senate did not give the same intensive scrutiny to nominees from its own chambers that it did to outsiders-a "senatorial courtesy" of a different sort. Those making the argument were opposed to Black and wanted a full investigation. The charge was also made that, after his court-packing defeat, President Roosevelt had to use the Senate in order to get a New Dealer on the Court to save his economic programs. ${ }^{61}$

John Marshall Harlan, nominated in 1955, was questioned about his membership in the Atlantic Union. ${ }^{62}$ In response, Harlan stated that he would not surrender United States sovereignty in favor of a world government. ${ }^{63}$ Another less crucial objection was that he was affiliated with the "Dewey-Brownell wing" of the Republican Party.

William Brennan's nomination in 1956 was contested in committee by Senator Joseph McCarthy. ${ }^{64}$ McCarthy wanted to know where Brennan stood on matters of internal security and berated the nominee for criticizing the methods of anti-communist investigations. ${ }^{65}$ Carefully attempting to avoid commenting on cases pending before the Court of which he was already a sitting member, Brennan indicated that he supported the use of congressional investigationsMcCarthy's chief tool. ${ }^{66}$

60. J. Frank, Mr. Justice Black: The Man and His Opinions 99 (1949).

61. MASON 467, 487.

62. Hearings lon the Nomination of John Marshall Harlan], supra note 33, at 129-47, 155$58,170-82$. Harlan was also asked about matters which related to cases which might come before him as a judge and about a previous Supreme Court decision. In both instances, Harlan refused to offer an answer, stating that to do so would be "inappropriate" or "improper." Id. at 137-138, 166-67. Harlan also gave no opinion of the Bricker Amendment, first proposed in 1952, which would have restricted the President's power to enter into executive agreements with foreign governments. He did add, however, that if the Constitution were amended, he would endeavor to uphold it as amended. Id. at 172-73.

63. Id. at 139, 142. In reply to a question of Senator Dirksen (R., III.), Harlan said that he had joined the Atlantic Union at the suggestion of Justice Owen Roberts, believing it to be against Communism, and that membership did not reflect any negative attitude about national sovereignty. Id. at 155. See also Thorpe, supra note 6, at 384-85.

64. Hearings Before the Senate Comm. on the Judiciary lon the Nomination of William Joseph Brennan, Jr.J, 85th Cong., 1st Sess., at S-6 (1957).

65. Id. at 17-19.

66. Id. Brennan received the support of Senator Dirksen, but his chief advantage was the strong endorsement he had received from Chief Justice Arthur Vanderbilt of the New Jersey Supreme Court, of which Brennan had been a member. This support and that of the bar was sufficient to overcome the opposition of Senators McCarthy and Eastland. Eastland had been 
It was alleged that Carswell was intellectually incapable of handling the job of Supreme Court Justice. ${ }^{67}$ Further, a variety of his actions indicated a commitment to racial segregation. While most senators were willing to forgive Carswell's allegedly racist campaign speech in $\left[948,{ }^{68}\right.$ other evidence, such as the signing of the incorporation papers which transformed a municipal golf club in Tallahassee into a private club to avoid desegregation, being a charter member of a private white men's club, and signing a deed to property which contained a racially restrictive covenant, indicated that the speech was not an isolated incident, but was part of a pattern which continued through the 1960's. ${ }^{69}$ The accumulation of such evidence embarrassed senators committed to voting for Carswell. Florida's Republican Gurney, who might have been expected to take the lead in pressing for confirmation of a nominee from his own state, did little more than read letters of support from his constituents into the Congressional Record. ${ }^{70}$ Many other senators who voted for Carswell were unable to give him any additional support beyond their votes.

Carswell's opponents also pointed to his alleged lack of candor in his appearance before the Committee. This charge can be illustrated by Carswell's actions in connection with the Tuttle letter. Former Chief Judge Tuttle of the Fifth Circuit wrote a letter to the Committee indicating both his willingness to testify as well as his confidence in Carswell as a judge. This letter was inserted in the hearings record. A few days later, but before Carswell's appearance, Tuttle telephoned Carswell, stating that he could no longer testify in support of the nomination. After Carswell's appearance, Tuttle, responding to an inquiry by Senator Tydings, characterized the letter as nothing more than an offer to testify, and further asserted that he, Tuttle, had "concluded that he could not testify in support of Carswell's nomination."' Senator Tydings, while expressly declining to

delaying the confirmation process because he disliked approving another liberal for a position on the Court.

67. Hearings (on the Nomination of G. Harrold Carswell]. supra note 34, at 239-42.

68. Carswell said, in part: "I believe that segregation of the races is proper and the only correct way of life in our state. I have always so believed and I shall always so act . . . I yield to no man . . . in the firm, vigorous belief in the principles of white supremacy and I shall always be so governed." Reprinted in 116 CoNG. Rec. 7853 (Mar. 18, 1970).

69. Memorandum on the Qualifications of G. Harrold Carswell, supra note 33.

70. 116 CONG. REC. 7654-55 (1970).

71. Id. at 7670. Tuttle further stated that he was "surprised to learn later that the letter was used for a purpose inconsistent with my decision not to testify as comniunicated directly to Judge Carswell." Id. at 7672 (emphasis added). 
charge Carswell with deliberate deception, urged senators to draw their own conclusions from Carswell's failure to withdraw the letter from the nomination record. ${ }^{72}$

When Lewis Powell and William Rehnquist were nominated, opposition centered on the latter, probably because of his conduct and views with respect to civil rights. On the other hand, opposition to Powell, at sixty-four the fourth-oldest nominee in the Court's history, was based upon what Congress' Black Caucus viewed as his inadequate performance concerning compliance with Brown while a member of the Richmond, Virginia School Board and the Virginia State Board of Education. ${ }^{73}$ Questions were also raised with respect to his occupying directorship posts in corporations which the Caucus believed to be in violation of the equal employment provisions of the 1964 Civil Rights Act. ${ }^{74}$

Opposition to Rehnquist, primarily by the Leadership Conference on Civil Rights and joined by the American Civil Liberties Union (opposing a nominee to public office for the first time in its history), was premised upon his opposition to the passage of a municipal public accommodations ordinance at a time when the 1964 Civil Rights Act was at final passage stage ${ }^{75}$ and his alleged participation in attempts in 1964 to deprive Arizona blacks of the vote. ${ }^{76}$ Rehnquist's earlier defense of Carswell in a letter to the Washington Post also drew the Leadership Conference's anger ${ }^{77}$ Further, Rehnquist's work as Assistant Attorney General on matters such as electronic surveillance and mass demonstrations led others to attack him for failure to appreciate the mandates of the Bill of Rights, despite arguments that he was only serving as the government's lawyer ${ }^{78}$ Rehnquist's assertion that the lawyer-client relationship between him and the rest of the executive branch made it impossible for him to divulge positions he had taken did not mollify liberal opponents. To this argument, opponents responded that he had indicated the intellectual compatibility of his views with those of the Justice Department.

Of particular interest was the charge, introduced quite late in the

72. Senator Eastland indicated that Tuttle had never requested withdrawal of the letter, which Eastland described as a "blanket endorsement." Id. at 7671.

73. Hearings on Powell \& Rehnquist 381-82.

74. Id. at 384 .

75. Id. at 307 (letter from Rehnquist to the Editor of the Arizona Republic).

76. Id. at $485-86,489-94$.

77. Id. at 358 .

78. Id. at $313,355,356,403,445$. 
campaign against Rehnquist's confirmation, that, while serving in 1952 as a clerk for Justice Robert Jackson, the nominee had written a memorandum supporting the Plessy v. Ferguson "separate but equal" doctrine. ${ }^{79}$ There are indications that, at the time, Justice Jackson opposed upsetting Plessy, although he later joined in the Court's unanimous decision undermining that case in Brown v. Board of Education. ${ }^{80}$ Because a clerk's duties include preparation of position papers, Rehnquist's memorandum could not reasonably be construed as clear evidence of his personal views.

Also stemming from his work as Justice Jackson's clerk was an article authored by Rehnquist in which he indicated that law clerks were ideologically to the left of both the justices and the nation. ${ }^{81}$ Interestingly, largely omitted in references to the article was the remainder of Rehnquist's argument, in which he indicated that it was specious to view law clerks as dominating Supreme Court Justices inasmuch as the opportunities for bias affecting the clerks' work were quite limited. ${ }^{82}$

Judicial Ethics and Conflict of Interest. The issue of the financial relationships of a judge with corporations and individuals involved in past or possible future litigation before him caused Justice Fortas to resign and raised troublesome questions over the Haynsworth nomination. At the time of Judge Parker's nomination, the New York Times reported that a question was likely to be raised concerning Parker's investments in utility securities; ${ }^{83}$ however, the matter was not pursued further. Assuming Parker was involved in business activities similar to those engaged in by Judge Haynsworth, the issue was perhaps not pressed because standards of judicial ethics were less stringent thirty years ago. However, no scandal had preceded the Parker nomination, whereas the Fortas controversy immediately preceded Haynsworth's nomination. Although Charles Evans Hughes had been accused of serving the interests of the wealthy-to some, prima facie evidence of corruption or dishonesty-this accusation was a different issue from that of conflict of interests. Certainly, standards for judges' withdrawal from participation in cases have

79. 163 U.S. 347 (1896).

80. 347 U.S. 483 (1953).

81. Rehnquist, Who Writes Decisions of the Supreme Court?, U.S. News AND WorLd REP., Dec. 13, 1957, reprinted in THE CouRTS 166-69 (R. Scigliano ed. 1962).

82. Id. at 169.

83. N.Y. Times, Mar. 22, 1930, at 18, col. 1. 
tightened in the intervening years, but the judge himself remains the sole decider of the propriety of withdrawal in a particular case. The issue of Haynsworth's stock purchases, which later proved to be his undoing, first surfaced several years before the nomination. An investigation at the behest of Attorney General Robert Kennedy by Chief Judge Sobeloff clearcd Haynsworth of unethical conduct in connection with the Darlington Mills case. ${ }^{84}$

Assessing the precise role of the ethics controversy in the rejection of Judge Haynsworth's nomination is difficult. Unquestionably, initial opposition to Haynsworth had been rooted in partisan and ideological considerations, and if the opposition had remained at that level, the nomination would almost certainly have been approved. However, as in the case of Justice Fortas, those who sought to block the nomination for political reasons uncovered evidence raising questions of ethical impropriety, a factor which may have changed the views of some who had originally been expected to support the nomination. While most senators who voted against Judge Haynsworth publicly attributed their opposition to the conflict of interest issue, it is reasonable to speculate in the absence of evidence to the contrary that the issue provided a convenient justification for opposition generated in fact by ideological or politicial considerations. The soundness of this conclusion is supported by a recent study of the roll-call votes on the Haynsworth and Carswell nominations which suggests that the liberal-conservative orientation, not party or region of the voting senators, was the important determinant of voting behavior. ${ }^{85}$

\section{Presidential Strategy in the Confirmation Process}

Presidential Support. As might reasonably be expected, the factor of presidential support has been significant in many controversial nominations. Of course, presidential support is presumed by the fact of nomination, and if the nomination is non-controversial, no additional exercise of presidential influence is required. However, if the nominee incurs significant opposition, additional and overt presiden-

84. 115 CoNG. Rec. 10390 (daily ed. Sept. 10, 1969). The investigation concluded in February, 1964. However, at the time of Haynsworth's nomination to the Supreme Court, Judge Winter, testifying in Haynsworth's behalf, did concede under questioning that he might have handled differently the acquisition of stock in a company whose case had already been decided but not published by his court.

85. M. Leavitt, Carswell and Haynsworth: An Elementary Study of Senate Voting, 1970 (unpublished manuscript). 
tial action becomes important.

President Wilson firmly supported Brandeis, ${ }^{86}$ and this support may have played a major part in deflating the opposition to the nomination. President Eisenhower's support of Earl Warren is also noteworthy in this regard. Objections to the Warren nomination involved the propriety of the President's making appointments during a congressional recess as well as a demand by Senator Willian Langer for patronage for small states ${ }^{87}$ Attempting to achieve his goal by intensive examination of minor complaints in the case of Warren, Senator Langer aired his charges at a hearing of the Judiciary Committee. Following the hearing, President Eisenhower promptly and strongly defended his nominee with a public statement and a letter to the Committee, ${ }^{88}$ thereby indicating firm White House support for the nominee.

Presidents have not always restricted themselves to public statements in attempting to marshal support for a nominee. For example, President Hoover, while maintaining a "low profile," called in three senators from his own party to gain support for Judge Parker's nomination..$^{89}$ However, presidential support may, in fact, not be effective, as is demonstrated by the failure of President Johnson's efforts on behalf of Justice Fortas' nomination for Chief Justice; indeed, this support, in view of the charges of "cronyism" leveled against Justice Fortas, may actually have been embarrassing.

President Nixon's strategy with respect to the nominations of Judges Haynsworth and Carswell provides an interesting contrast in the use of presidential power. Actively supporting both nominations, the President exerted heavy pressure in Haynsworth's behalf virtually from the time the nomination was first challenged in the Senate. The President devoted a special news conference to the defense of Haynsworth, where a detailed refutation of the conflict of interest charges made against the nominee was presented. ${ }^{90}$ Unwilling to stop with such a refutation, President Nixon further argued that senators

86. See TODD 133-139.

87. See McKay, supra note 7, at 133-34; cf. Grossman 118. See also 100 Cong. Rec. 2045 (1945) (remarks of Senator Langer).

88. Support from within the Administration also came from Attorney General Brownell, Deputy Attorney General Rogers, and Vice President Nixon. The only negative votes cast in Committee were those of Democrats Eastland, Johnston and Kilgore.

89. Hoover later wrote about senators who "ran out" on him. 2 H. Hoover, supra note .36, at 269.

90. N.Y. Times, Oct. 21, 1969, at 34. 
should not take a judge's philosophy into account in making a confirmation decision and indicated strong disagreement with senators who would vote against confirmation on the basis of a disagreement with a nominee's political or legal philosophy. ${ }^{91}$

Judge Carswell's nomination, like Haynsworth's, was considered a part of President Nixon's "southern strategy." ${ }^{2}$ Carswell, impeccable in his financial dealings, encountered more opposition from blacks and white liberals than did Judge Haynsworth..$^{93}$ Because of resentment by Republican senators who previously had been the object of "arm-twisting" tactics, the President adopted a more cautious approach with respect to the Carswell nomination. Accordingly, there was little initial overt White House pressure; however, later, when the nomination was in trouble, President Nixon tried to apply a different kind of pressure through his letter to Senator Saxbe, ${ }^{94}$ which, as suggested, did not halt the trend away from Carswell. The Administration, in a defensive position throughout the Carswell affair, was caught short-handed by revelations of Carswell's racial statement and was unprepared to respond to other allegations about Carswell's alleged support of racial segregation, indicating that neither Nixon nor his Attorney General knew very much about the man they had nominated to the Supreme Court. ${ }^{95}$ In the final analysis, the

91. Id. cols. 3-5.

92. In fact, two national columnists suggested that because of this strategy, Attorney General Mitchell twice refused Haynsworth's request that his name be withdrawn. Evans \& Novak, Mitchell's Strategy on Haynsworth Strains Republican Party Relations, The Washington Post, Nov. 24, 1969, at A-13, col. 1. Judge Haynsworth subsequently denied that he had made such a request. The confirmation of Lewis Powell, after the attempt to name Rep. Richard Poff (R., Va.) was aborted when he withdrew from consideration, has probably satisfied whatever obligations President Nixon had in this regard.

It is also possible that Parker's nomination resulted from the "southern strategy" of a Republican President. While Hoover's Attorney General did indicate in a memorandum to the Senate Judiciary Committee that the fact that the Fourth Circuit had not been represented on the Supreme Court in many years played a part in Parker's selcction, he claimed that a search for nominees had been made in several circuits, not all of which were southern. A Department of Intcrior official urged selection of Parker in order to reward North Carolina and the South for electoral support of Hoover, but there is no way of knowing the actual effect of his suggestion. Hoovcr insisted that his Attorney General had demanded "quality and character on the bench," but did indicate that "regional distribution of justices had always been regarded as of some importance." $2 \mathrm{H}$. HOOVER, supra note 36 , at 268 .

93. E.g., Hearings /on the Nomination of G. Harrold Carswell], supra note 33, at 134, 235.

94. See note 4 supra and accompanying text.

95. A developing credibility gap increased when the Justice Department ignored the requests of several senators to meet privately with Carswell. As most of the senators in this group were otherwise likely to vote against Carswell, the meeting could not have hurt, and might have helped. 
Administration's support and pressure did not provide individual senators with ample reasons to take the political risks involved in supporting the nomination. Thus, the President's strategy defied a basic criterion of effective use of presidential power-persuading individuals that what the President desires is in their own interest as well..$^{90}$

President Nixon's presentation of the nominations of Powell and Rehnquist-his principal "intervention" with respect to those nominations-was quite significant. The nominees were generally a surprise, coming as they did after the release of a list of six possible nominees, with the clear indication that Herschel Friday and Mildred Lillie were those preferred. ${ }^{97}$ Before President Nixon's nationally televised nomination speech, it had become clear that the ABA committee was negatively disposed to both Friday and Lillie and that their prospects for receiving Senate approval were poor..$^{98}$ Whether the "list of six" was a smokescreen meant to draw off the opposition of the Senate liberals or whether President Nixon simply managed to extricate himself from another situation in which the Justice Department had allowed the recommendation of less than superbly qualified nominees is unclear. In either case, the President's dramatic announcement was clearly helpful to the nominees' cause.

Timing of Nominations. The timing of both the Parker and Haynsworth nominations appears significant. The strength and effectiveness of the opposition that developed is highlighted because the Haynsworth nomination, early in Nixon's term of office, should have benefited from some residual "halo" effect from his election. Hoover's nomination of Parker was late in the term, after the socalled "honeymoon" with Congress had waned..$^{99}$ Furthermore, the Parker nomination occurred shortly after the controversy over the

While this information lag proved acutely embarrassing to the Nixon Administration, it may have reflected bad luck rather than a unique incompetence. The evidence suggests that the intelligence system by which both the ABA Committee on Federal Judiciary and the Justice Department get their information on prospective judicial candidates is sporadic rather than systematic. The Kcnnedy Administration was misled several times about the segregationist views of prospective federal judges in the South. See V. NAVASKY, KenNedY JUSTICE 265-66 (1970). See generally Grossman 108-13.

96. $C f$. R. Neustadt, Presidential Power: The Politics of Leadership 7 (1960).

97. Nixon's Court: Its Making and Its Meaning, TiME, Nov. 1, 1971, at 16-17.

98. The probability of a protracted fight over Rep. Poff had caused him to have his name withdrawn earlier. N.Y. Times, Oct. 3, 1971, at 1, col. 1.

99. Professor Scigliano argues that nominations made in the first three years of a President's term have generally been accepted. Nominations in the last year of a term or in a lameduck period have had much less success. R. Scigliano, supra note 59, at 98. 
nomination of Charles Evans Hughes as Chief Justice. ${ }^{100}$ While Hughes was confirmed, sixty-two to twenty-six, there had been strong minority opposition from Progressive Republicans led by Senator Norris. Thus, when Parker's name was submitted to the Senate, there was already controversy and political opposition to the President over a judicial appointment. ${ }^{101}$ As to President Nixon's nominations, while the nomination of Warren Burger as Chief Justice prior to the nomination of Judge Haynsworth had been confirmed with less protracted opposition, there had been significant liberal dissatisfaction with the Burger appointment, particularly over his views and prior decisions on criminal procedure. However, more important to the Haynsworth controversy than the residual effect of a prior contested nomination are the two battles over Abe Fortas-first, over his nomination as Chief Justice and second, over the conflict of interest charges which led to his resignation in 1969. Nevertheless, in both the Haynsworth and Parker cases, frustration by opposition senators over a previously lost fight seems to have increased the nominee's vulnerability to attack.

President Nixon chose to wait several months after Judge Haynsworth's defeat, presumably to let troubled waters calm somewhat, before sending Judge Carswell's nomination to the Senate. However, this delay may have been a mistake, because immediately after the Haynsworth debate, the Senate was probably in a mood to confirm virtually any nominee. ${ }^{102}$ Many senators who had opposed Haynsworth were concerned with possible damage to the Court resulting from the Fortas and Haynsworth conflict of interest charges, and it seems likely that Carswell might have been approved had his nomination been submitted earlier. Indeed, when the nomination was announced, there seemed little inclination to contest the selection by many of the liberals and moderates whose coalition had defeated Haynsworth, but an additional delay of several months permitted revitalization of the coalition, which then produced damaging evidence against Carswell.

Timing also appeared to be important in the Rehnquist conflrma-

100. See generally 2 M. Pusey, Charles Evans Hughes 648-62 (1951). Hughes had been attacked as a "tool of capitalism" and for encouraging political activity on the part of Supreme Court Justices by resigning in 1916 to run for President. Id. at 655.

101. Harlan Fiske Stone attributed Parker's rejection in part "to the debate and hard feeling that was stirred up over the Hughcs nomination." Mason 300.

102. See Reston, Washington: President Nixon's Gamble, N.Y. Times, April 3, 1970, at 36 , col. 3 . 
tion. The Powell and Rehnquist nominations came toward the end of the congressional session when the Senate was attempting to expedite completion of its business. Moreover, the nomination of Earl Butz as Secretary of Agriculture, confirmed by a close margin, had exhausted considerable Senate energy. Furthermore, substantial Senate attention had been devoted to attacks upon the anticipated nominations first of Congressman Poff and then of Friday and Lillie.

Nominee's Appearance Before the Senate Judiciary Committee. The significance of a nominee's appearance before the Judiciary Committee is indicated by the case of Harlan Fiske Stone. Although Stone's nomination to the Court by President Coolidge resulted in sentiments to the effect that the nominee had been "kicked upstairs" because of his firmness as Attorney General and because he was overly aggressive with respect to antitrust matters, ${ }^{103}$ major opposition within the Senate did not seem likely. However, one Ownbey, disgruntled over a lawsuit between himself and J.P. Morgan, who had been represented by Stone, demanded that Stone not be confirmed. ${ }^{104}$ Ownbey found a champion in Senator Heflin of Georgia, ${ }^{103}$ but the nature of the attack pressed by Senator Heflin drew attention away from other issues which might have arisen, such as Stone's relation to "big money" interests. It was Stone's handling of the case, not his representation of Morgan, which drew Ownbey's ire. ${ }^{108}$

After the delay caused by the Ownbey matter, the Judiciary Committee approved the nomination. ${ }^{107}$ However, Senator Walsh of Montana attacked Stone on the Senate floor in an executive session for his role as Attorney General in a matter involving Montana's other senator, Burton Wheeler. ${ }^{108}$ Senator Wheeler had been indicted for practicing as an attorney before a government agency while serving as a senator. A Senate committee exonerated Wheeler, but Stone had refused to drop the charges and had instituted an expanded investigation into the matter, ${ }^{109}$ a fact which gave rise to Senator Walsh's opposition. After Stone, contrary to custom, expressed a willingness to appear before the Judiciary Committee in a public session, the

103. While Coolidge may have wanted him out of the way, there was also a "pull" from the Court-Taft seems to have played a role in the nomination. MAson 184.

104. See id. at 185-88.

105. See 66 Cong. Rec. 2511,3046 (1925).

106. MASON 187.

107. Id. at 146.

108. Id. at 188-96.

109. Thorpe, supra note 6 , at 375 . 
Senate unanimously sent the nomination back to Committee. Stone's appearance before the Committee "was a complete success for the Republican party and a personal trimph for himself."110 Even Senator Walsh changed his position and abstained on the confirmation vote instead of opposing Stone.

It has been suggested that Judge Parker's failure to testify personally diminished his prospects for confirmation. ${ }^{111}$ A personal appearance before the Judiciary Committee might have removed doubts about his views on racial issues, but since such was not the custom at the time, Parker did not appear. ${ }^{112}$ Judge Haynsworth, on the other hand, appeared before the Judiciary Committee personally, pursuant to current custom. Whether his appearance affected the votes of any senators on the Committee is unclear, although the refusal to address himself to charges of unethical conduct-as opposed to charges of mere political oratory-might well have been damaging. With Judge Carswell, the problem turned out not to be an appearance before the Judiciary Committee, which he made in due course, but the failure of the Department of Justice to arrange for the nominee to meet privately with key senators. As is now accepted practice, both Justices Powell and Rehnquist appeared to testify. ${ }^{113}$ When a variety of allegations concerning the latter nominee surfaced after his two-day hearing, Rehnquist sent affidavits denying the charges to Judiciary Committee Chairman Eastland. ${ }^{114}$ This action, however, was considered insufficient for the Committee's dissenting senators, who tried unsuccessfully to schedule another day of hearings and who attacked the nominee for failing to clarify matters adequately for the Senate. ${ }^{115}$

\section{Group Support or Opposition}

Organized support or opposition by special interest groups has been crucial in several nominations and is probably more influential at the pre-nomination stage, because a President generally will not designate a nominee strongly opposed by groups associated with the fortunes of his own party. However, as might be expected, groups

I10. MASON 197.

111. Thorpe, supra note 6 , at $374-75$.

112. Id. at 375 .

113. Rehnquist appeared before the Committee on two different days, Nov. $3 \& 4,1971$. Powell made only one appearance, on Nov. 8, 1971. Hearings on Powell \& Rehnquist 16, 137, 201.

114. Id. at 486-92.

115. 117 CONG. Rec. 20550 (daily ed. Dec. 3, 1971). 
normally not associated with the President's party are unlikely to be influential in opposing the nomination unless they can provide substantial evidence demonstrating either the candidate's complete lack of qualifications or his adherence to views unacceptable to either political party. In the case of Brandeis, to neutralize opposition from leading segments of the bar, supporters of the nomination made staff help available to the Judiciary Committee, thereby presenting their position directly to the senators. Also, despite the opposition to the nomination by many prestigious lawyers, a marked division of opinion in the legal community existed with considerable support for the nomination coming from law professors. ${ }^{116} \mathrm{~A}$ split of practicing attorneys and professors over a nomination also occurred in the Haynsworth and Carswell nominations with the professors opposing and the practitioners supporting confirmation.

The coalition of groups opposing both Judges Parker and Haynsworth and the ideological and policy basis for their opposition perhaps provides the strongest parallel between the two rejections. The principal components of the coalition were the NAACP and organized labor, joined by liberal Democrats and progressive Republicans. In both instances there was an element of political hostility toward the nominating President, a factor which was difficult to separate from opposition to the nominees themselves.

The NAACP and labor based their opposition to Parker on single events-the former on Parker's statement made when he was a Republican candidate for Governor of North Carolina, ${ }^{117}$ the latter on his decision in $U M W v$. Red Jacket. ${ }^{118}$ In the Haynsworth controversy labor again premised its opposition on a single case. ${ }^{119}$ While the basis of the NAACP's opposition to Haynsworth was somewhat more complicated, essentially the organization maintained that the nominee had not carried out the spirit of the Brown decision but had, on the contrary, approved a variety of school desegrega-

116. For example, the Harvard Law School Faculty was pro-Brandeis, even though President Lowell of Harvard opposed the nomination. ToDD 258.

117. Neither Walter White of the NAACP nor William Green of the AFL appeared to know more about Parker than these single events to which they objected, nor had they known about Parker prior to his nomination. In fact, the North Carolina labor groups had first endorsed Parker, either without knowing of, or in spite of, UMW v. Red Jacket Consol. Coal \& Coke Co., 18 F.2d 839 (4th Cir. 1927).

118. 18 F.2d 839 (4th Cir. 1927).

119. Darlington Mfg. Co. v. NLRB, 325 F.2d 682 (4th Cir. 1963), vacated and remanded, 380 U.S. 263 (1965). 
tion plans designed to avoid rather than promote integration. ${ }^{120}$

However, in both the Parker and Haynsworth cases, the underlying reasons for NAACP and labor opposition went beyond particular events. In reality, opposition may have been as much related to political circumstances attendant to the nominations as to the individual nominees themselves. At the time of the Parker nomination, both the NAACP and labor had relatively little political power; consequently, blocking the Parker nomination was a major symbolic victory for both groups. Moreover, the opposition to Parker was a continuation of the liberal attack on a conservative Court. Both organized labor and the NAACP, stronger politically by the time of the Haynsworth, ${ }^{121}$ Carswell and Rehnquist nominations, may have felt it necessary to block the nominations to protect interests which they thought Nixon's nominees would oppose if they were on the Supreme Court. With their influence confined principally to the Democratic party, the two groups perhaps felt compelled to strike at least a symbolic blow against the judicial fruits of the President's "southern strategy" inasmuch as the prospect of a Republican President's appointing several justices raised the spectre of the Supreme Court, long perceived as the most liberal branch of government, moving substantially toward the right. Unlike the Parker case, where opposition was motivated in part by a desire to alter radically the policies of the Court, opposition in the Haynsworth, Carswell and Rehnquist cases was a desperate effort to maintain the Court's prevailing policies.

Lawyers and the $A B A$. The prospects for confirmation of Judges Carswell and Haynsworth were diminished by severe criticism of leading lawyers and law professors. The statement by the former Dean of the Yale Law School, Louis Pollak, that Judge Carswell "presents more slender credentials than any nominee for the Supreme Court put forth in this century," ${ }^{222}$ was widely quoted and apparently widely believed. ${ }^{123}$ As was well publicized, these statements provoked

120. A South Carolina labor union and some NAACP attorneys, counter to the views of their national leadership, said that Haynsworth was a fair and honest judge. 115 CoNG. REC. 34458 (1969).

121. In 1930, labor may have felt the need to demonstrate publicly its growing political clout. Likewise, the NAACP was still a fledgling organization, dependent largely on white liberals, and under attack from the Communist Party as being too conservative and establishment oriented.

122. 116 CONG. REC. 2860 (1970).

123. See also the comment by Joseph Rauh, that Carswell is a "Judge Haynsworth with a cutting edge. . . . with a bitterness and a meanness that Judge Haynsworth never had." 116 CONG. REC. 2415 (1970). 
Senator Roman Hruska of Nebraska to proclaim the need to represent mediocrity as well as ability on the Supreme Court, a statement used effectively against Carswell. ${ }^{124}$

Carswell's nomination also failed to receive a strong endorsement from the ABA's Committee on Federal Judiciary. The Committee previously rated nominees to the federal bench as "exceptionally well qualified," "very well qualified," or "not qualified." A development adversely affecting the Carswell nomination occurred shortly after the Haynsworth nomination when the Committee shifted to a "qualified" or "unqualified" measure for Supreme Court nominations, rating Carswell "qualified"-by a majority rather than a unanimous vote. ${ }^{125}$ Standing alone, the term "qualified" seemed to lend credence to the charge that Carswell was rated as average, even though there was no higher rating the Committee could have given him. In effect, the ABA rating served only to reinforce other negative judgments about Carwell's qualifications. ${ }^{126}$ While there was isolated support for Carswell from laywers and local bar groups, the preponderance of legal opinion was negative. ${ }^{127}$

The problems of the ABA with respect to its rating system as applied to Carswell led to another modification of the system. Beginning with the nomination of Justice Blackmun, the ratings were changed to "not qualified," "not opposed," or "meet high standards of integrity, judicial temperament and professional competence." 128 The ABA also gained from the Attorney General a concession to the effect that the former practice of allowing the Committee on Federal

124. The claim about Carswell's competency provides a parallel to the nomination of McKenna at the end of the last century. The defense of McKenna by Senator White, Chairman of the Judiciary Committee, was that McKenna was not a legal giant but was competent. $C$. W. King, Melville Weston Fuller: Chief Justice of the United States 228-30 (1950).

125. The ABA had decided in 1962 to use only "qualified" or "unqualified" with respect to the Supreme Court because the nominations were not cleared with the Committee in ad. vance. It then shifted to "highly acceptable," "acceptable," or "not acceptable" from the viewpoint of professional qualifications prior to Haynsworth's nomination. See generally Grossman 75-80; Walsh, Selection of Supreme Court Justices, 56 A.B.A.J. 555 (1970). See note 128 infra.

126. Grossman 75-80.

127. For example, the faculty of Florida State University Law School, of which Carswell was a founder, opposed the nomination. 116 CONG. REC. 10245 (1970) (remarks of Senator Tydings).

128. Cf. Report of the Standing Committee on Federal Judiciary, in 95 REPORTS OF THE AMERICAN BAR Ass'N 1970, at 711 (1971).

The Committee's report notes the differing ratings given the three nominees, but offers no explanation for the rating system changes. 
Judiciary to evaluate all possible nominees for a Supreme Court position, rather than simply the one man already selected, would be resumed. ${ }^{129}$ It is likely that this change was less a result of ABA prodding than of the Justice Department's embarrassment over what post-nomination investigations revealed about Haynsworth and Carswell.

This shift to allowing the Committee to make prior evaluations led to the first instances in which the Committee had ever made a negative recommendation on Supreme Court nominees. The Committee voted eleven to one that Judge Lillie was unqualified. ${ }^{130}$ With eight votes necessary for a "qualified" rating, it voted six to six on Herschel Friday, who thus came out "not opposed."131 Irritated by the supposed leak of the nominees' names, President Nixon announced, at the same time that the Powell and Rehnquist nominations were made, that the ABA would no longer enjoy the opportunity to make its evaluations before the Supreme Court nominations were submitted to the Senate. ${ }^{132}$

\section{CONCLUSION}

The Senate's consideration of Supreme Court nominations in the twentieth century is notable because of the routine treatment and high expectation of confirmation in most cases. Of the long delays in about one-fourth of the nominations, some were caused by substantial opposition, rendering eventual confirmation questionable, but in others, delays resulted from a variety of idiosyncratic reasons not initially regarded as threats. The Senate Judiciary Committee approved all but one nomination, with relatively few dissenting votes cast by Committee members, and there was generally little delay between the Committee's report and confirmation by the full Senate. While all of the defeated nominations encountered substantial delays, so did a miscellany of others which were not seriously threatened. Delay in many cases seemed related to regional constituency interests of minority bloc senators, or attempts to embarrass the President or criticize the Supreme Court, rather than serious efforts to defeat a nomination. In some cases delaying tactics were used to postpone a final

129. Letter from Attorney General J. Mitchell to B. Segal, President of American Bar Ass'n, reprinted in Report, supra note 128, at 713 (1971).

130. Nixon's Court: Its Making and Its Meaning, supra note 97, at 17.

131. Id.

132. Id. 
determination until additional unfavorable information and/or opposition votes could be obtained. However, as a general proposition, the confirmation process has been based on the assumption that the President should be allowed to make any reasonable choice and that the "burden of proof" as to a nominee's lack of qualifications must be sustained by the opposition. Thus, an effective strategy of opposition entails mobilizing a majority of senators against the President and developing positive reasons as to why a particular nominee should not be confirmed-not merely vague opposition or a preference for unnamed others who might have received the nomination.

Since World War II, Supreme Court nominations have been characterized by longer delays, more lengthy and detailed hearings by the Senate Judiciary Committee, and a fuller participation in these hearings by the nominee himself. A result of the Fortas, Carswell and Haynsworth cases may be to increase the range of investigative inquiry engaged in by the Senate. At present, the Senate Judiciary Committee has no formal investigative apparatus and relies for the most part on information supplied to it by the executive branch; however, it seems unlikely that this practice can or will continue. Until now, the burden of combating information provided by the Administration has fallen on the opposition, but the unreliability and incompleteness of information accompanying the nominations of Haynsworth and Carswell may make it imperative for the Senate Judiciary Committee, for its own protection, to develop and institutionalize investigative practices. Also, future nominees will undoubtedly be required to provide more information concerning their backgrounds and, in particular, about their financial dealings. The development of these trends will further dilute the assumptions of presidential prerogatives. The new concern over judicial ethics brought about by the Haynsworth and Fortas nominations will undoubtedly provide a surrogate for opposition on partisan or ideological grounds which might otherwise be regarded as illegitimate. There appears to be no weakening of presidential prerogative to nominate almost exclusively members of his own party or those with whom he has an ideological affinity, but there appears to have developed a fairly strong barrier to anyone whose views on racial questions are suspect, as is the case with other "extremist" policy views. ${ }^{133}$

133. The confirmation of Mr. Rehnquist, whose views on racial equality and the use of the law to combat discrimination were at best ambiguous, might at first glance appear to contradict this assertion. It is more likely, however, that the evidence against him was not as persuasive 
These developments suggest possible changes in the strategies of future Presidents with respect to making nominations and expediting Senate confirmation. Presidents may be well advised to justify their choices more extensively and to increase consultation with Senate leaders, thus co-opting their support when the nomination is actually presented. Much in the manner that Senate leaders are regularly included in treaty delegations, they perhaps may also have to be consulted informally regarding Supreme Court nominations. Also, Presidents may be ill-advised to utilize certain heavy pressure tactics, perhaps legitimate in support of major legislation, but which enraged a number of senators at critical points in the Haynsworth and Carswell cases. Such tactics seem peculiarly inappropriate where the President's party does not control the Senate. ${ }^{134}$

The close scrutiny likely to be given to a nominee's background makes it almost inevitable that damaging evidence can be found. Most of the controversial Supreme Court nominations in the twentieth century involved men who have had intricate financial and business dealings. It was, therefore, not suprising to find some of these individuals to have been involved in, or connected with, actions which, though not illegal, appear in retrospect ill-advised and indicative of faulty judgment. Likewise, anyone who serves as a judge is likely to have made decisions which either were in error or incurred the ill-will of formidable enemies. Thus, despite the current rhetoric of the bar and many politicans favoring prior judicial experience as a prerequisite to appointment, Presidents may find it preferable to give appointments to men with different and less vulnerable backgrounds.

as in the case of Carswell. Rehnquist's opposition to a public accommodations statute in Phoenix was based on an asserted lack of governmental power to regulate individual behavior in this way. For some opponents this was merely sophisticated racism, but for others, it did not exceed acceptable limits.

134. It has already been suggested that President Nixon's novel television announcement of the Rehnquist and Powell nominations was an effective device. See note 98 supra and accompanying text. He made it clear that his nominees share his judicial philosophy of strict construction of the Constitution, and that they were committed to a "law and order" philosophy. It was, by all odds, a sophisticated appeal for political support for confirmation.

The utility of pressure tactics will, of course, vary with the situation at hand. It has been suggested, off the record, that President Nixon "held hostages" by not submitting the names of nominees to other judicial vacancies until Powell and Rehnquist were confirmed. If this was indeed true, then it is clear that the President was anticipating a close showdown vote. Since the votes for confirmation were not close, it is not clear what effect such tactics might have had. 
Finally, the rejections of Haynsworth and Carswell may lend additional support to those who have advocated radical changes in the process of selecting federal judges. There are two ways of assessing the performance of the Senate in light of the Carswell and Haynsworth nominations. One could argue that in rejecting both men, the Senate demonstrated the efficacy and need for its services in the selection of judges. In both cases, the Senate clearly played the constitutional role assigned to it by obtaining a relatively comprehensive view of the values and abilities of each of the nominees and by making an independent assessment of the qualifications of a presidential nominee. Throughout the confirmation process, senatorial opponents of both Haynsworth and Carswell were able to elicit substantial information about both candidates which was overlooked or not revealed by the executive branch. The Senate's actions, whatever one might think of them substantively, reflect not a passive but an active role for the Senate in Supreme Court nominations.

On the other hand, the spectacle of the President and the Senate locked in combat over the Supreme Court for nearly a year is undoubtedly disturbing to many who feel that the Court should be allowed to remain aloof from the political arena. It has been suggested that because the Court is not a truly political institution the selection of Supreme Court Justices through an inherently political process is inconsistent with the role and functions of the Court. A number of alternatives have been suggested by the organized bar, including a federal version of the "Missouri Plan" by which judges are selected in some states. ${ }^{135}$ Under the proposal, a bi-partisan nominating commission would, for each vacancy on the Court, submit to the President two or three names from which the President could choose one. The nomination would still require Senate confirmation. Some supporters of the proposal would go further and, through a constitutional amendment, eliminate the role of the Senate entirely. The commission would be composed of lawyers and laymen in equal numbers and chaired by the Chief Justice or, if the position to be filled was the Chief Justiceship, by the senior associate justice on the Court. The lay members would be chosen by the President and the lawyer-members by the bar. The avowed purpose would be to take the selection of judges "out of politics." However, the unstated pur-

135. See, e.g., R. Watson \& R. Downing, Thb Politics of the Bench and the Bar (1969). 
pose and result would be to increase the power of the bar over judicial nominations.

The problem with this plan is that, rather than eliminating politics from the selection process, the scheme would only transfer the forum in which politics would operate. One set of political actors would be replaced by another, namely administratively chosen laymen and lawyers instead of popularly electcd senators. It is probably unlikely that such a panel would, over the long run, make selections substantially different from those nominated during the last several decades. However, a result of the plan would be to lessen the visibility of the selection process, as well as the already low visibility of the Court itself. ${ }^{136}$ Such a plan might increase confidence in the Court for some lawyers, but it would probably reduce public confidence in the Court and further remove it from the mainstream of American politics. In an age of momentous social change, the Court has become to some Americans the only responsive governmental institution. The Court can remain responsive only if its members are rccruited from the ranks of those with both political and legal experience and selected by others who have similar experience. The tortuous process by which the Senate rejected Judgcs Haynsworth and Carswcll is a far more democratic and useful procedure than the process contemplated by the "Missouri Plan." It is also inherently preferable to the President's claim to virtually sole dominion over the selection of Supreme Court Justices.

136. See Murphy \& Tanenhaus, Public Opinion and the United States Supreme Court: A Preliminary Mapping of Some Prerequisites for Court Legitimation of Regime Changes, in Frontiers of Judicial RESEARCH 273, 276-80 (J. Grossman \& J. Tanenhaus, eds. 1969). 
, 